\title{
The Effect of Hypnobreastfeeding on Increased Milk Production in Breastfeeding Mothers of Perlis Village, Tangkahan Durian District, of North Sumatera, Indonesia
}

\author{
Julieta Hutabarat $^{1}$ \& Kirana Patrolina Sihombing ${ }^{2}$ \\ ${ }^{1}$ The Midwifery Study Program, Medan Health Polytechnics, Ministry of Health Indonesia \\ ${ }^{2}$ Dental Health Study Program, Medan Health Polytechnics, Ministry of Health Indonesia \\ Correspondence: Kirana Patrolina Sihombing, The Dental Health Study Program, Medan Health Polytechnics Of \\ Ministry Of Health, Indonesia. Tel: 62-852-9602-2434
}

Received: October 16, 2020 Accepted: December 25, 2020 Online Published: February 10, 2021

doi:10.5539/gjhs.v13n3p112 URL: https://doi.org/10.5539/gjhs.v13n3p112

\begin{abstract}
Background/Aim: To ascertain Hypnobreastfeeding on increased milk production in Breastfeeding Mothers of Perlis Village, Tangkahan Durian District, in Nort Sumatera of Indonesia.

Methods: A Quasy experiment study with non-equivalen control group approach with purposive sampling. A total of 24 samples randomly selected become as many as 12 people were given hypnobreastfeeding treatment and 12 people were not treated with the inclusion criteria age of infants were 10 days - 1 month, mother's $\mathrm{Hb} \geq 12 \mathrm{~g} \%$ and infants were not given formula milk during the study. Data entry was done manually but the analysis was done with the SPSS version 12 programme. Results were presented as distribution frequencies.

Results: Hypnobreastfeeding was significantly increase milk production in breastfeeding mothers ( $p$ value $=0.001$ ). The mean of initial breast milk in the hypnobreastfeeding group was $78.92 \mathrm{ml}$ SD 2.15 and after treatment became $93.94 \mathrm{ml}(\mathrm{SD}=5.23)$. The findings of the study were compared with previous studies and the researchers showed how the relevant theories that guided the study were used to explain the findings.

Conclusion: Hypnobreastfeeding treatment could increased milk production of breastfeeding mothers. So, the counseling of Hypnobreastfeeding treatment was necessary to breastfeeding mothers even to mothers during pregnancy.
\end{abstract}

Keywords: hypnobreastfeeding, increased breast milk production

\section{Introduction}

\subsection{Background}

Breast milk is the first, main and best food for babies that is natural because it contains various nutrients needed in the process of baby growth and development. Breastfed babies suffer from disease less frequently and avoid internal and external problems (Maryunani \& Anik, 2012). Exclusive breastfeeding is breastfeeding without additional food at the age of 0-6 months (Abdiasis et al., 2020). The World Health Organization (WHO) reports that exclusive breastfeeding until the age of six months can prevent the death of more than 200 thousand babies each year. The percentage of achievement of exclusive breastfeeding is still low. The coverage of infants who received exclusive breastfeeding for up to 6 months in Indonesia was $29.5 \%$ and those who received exclusive breastfeeding for 0-5 months were 54\%. North Sumatra Province, for the coverage of infants who receive exclusive breastfeeding for up to 6 months is $12.4 \%$ and infants who receive exclusive breastfeeding for $0-5$ months are $46.8 \%$.

The failure of exclusive breastfeeding caused by the low milk production. Breast milk production was influenced by the hormones prolactin and oxytocin. The production of these hormones were greatly influenced by the psychological condition of the mother, and also the production of prolactin and oxytocin. Psychological factors have a big influence on milk production because the release of milk from the breasts is smoother when the mother is relaxed and comfortable. Psychological factors affect $70 \%$ of breast milk production (Werdayanti \& Rina, 2013). 
Therefore it was necessary to have a stimulus to keep mothers relaxed, confident so that they can accelerate milk production, especially on the first day of breastfeeding. One of the solutions that can help overcome the low milk production barrier in exclusive breastfeeding was hypnobreastfeeding (Eva et al., 2016).

According to Indriyani and Asmuji (2016) that hypnobreastfeeding intervention is one of the mother's preparations in terms of mind (mind) including peace of mind aims to make mom comfortable and able to produce sufficient breast milk to meet the baby's growth and development needs. Peace of mind and a mother's sincerity to breastfeed her baby are equally important supporting factors with physical preparation such as eating with balanced nutrition, drinking enough, breast massage, and learning proper to breastfeeding management.

The results of the research by Putriningrum et al. (2015) on the effect of knowledge and hpynobreastfeeding on third trimester pregnant women on the breastfeeding process in Sukoharjo show that giving hypnobreastfeeding therapy to the third trimester pregnant women affects the breastfeeding process. This is in line with the research of Asri, et al (2014) that mothers who get hypnobreastfeding are more likely to give exclusive breastfeeding than mothers who do not get hypnobreastfeeding. Research by Rahmawati, Anita and Bisepta Prayogi (2017) report that there is an effect of hypnobreastfeeding on breast milk production in working breastfeeding mothers with an average value of milk production increasing by $40 \mathrm{ml} /$ day and occurs constantly after hypnobreastfeeding.

Based on a preliminary study conducted in Perlis Village show that out of 23 breastfeeding mothers who had babies 0-6 months, none of them gave exclusive breastfeeding. They were only given starch water to increase the milk consumed by their babies and of the 5 breastfeeding mothers when asked about hypnobreastfeeding Everyone said they knew nothing about hypnobreastfeeding.

\subsection{Objectives}

The specific objectives are:

1) To quantify milk production in breastfeeding mothers who are not hypnobreastfeeding and given hypnobreastfeeding.

2) To Analyze the effect of hypnobreastfeeding on increased milk production in breastfeeding mothers associated with their demographic characteristics.

\subsection{Material Studied}

\subsubsection{Types of Breast Milk}

Breast milk was food for babies that contains high-quality nutrients which are useful for the growth and development of intelligence of infants/children. Breast milk is a gold standard baby food which is the first step in fulfilling children's rights. The types of breast milk consist of Colostrum, Transitional/intermediate milk, and Mature milk. Colostrum was the first milk secreted by the mammary glands on the first to the fourth postpartum day. The amount of colostrum produced varies depending on the baby's suction in the first days of birth. Colostrum volume between 150-300 ml/day. Transitional breastfeeding was milk that comes out after colostrum until before breast milk is ripe, from day 4 to day 10 . The volume of milk gradually increases, the immunoglobin concentration decreases and there is the addition of elements that produce heat (calorific content), fat and lactose. (Stables and Rankin. 2010). Mature breast milk was secreted on the 10th day and beyond. Mature breast milk looks yellowish white because it contains casineate, riboflaum and carotene. The content of mature breast milk is relatively constant, with volume was $300-850 \mathrm{ml} / 24$ hours. The breast milk also consist of antimicrobial factors, namely antibody against bacteria and viruses, Cells (phagosile, granulosil, macrophages, T-type lymphocytes), Enzymes (lysozyme, lactoperoxidese), Protein (Lactoferrin, B12 Protein Rollers), Factor resistant to staphylococcus, and Complement (C3 and C4) (Ashmika \& Rajesh, 2014).

Table 1. Composition of Colostrum

\begin{tabular}{llll}
\hline Compositon & Colostrum & Transitional & Mature milk \\
\hline Energy $(\mathrm{kgkal})$ & 57.0 & 63.0 & 65.0 \\
Lactosa $(\mathrm{gr} / 100 \mathrm{ml})$ & 6.5 & 6.7 & 7.0 \\
Fat $(\mathrm{gr} / 100 \mathrm{ml})$ & 2.9 & 3.6 & 3.8 \\
Protein $(\mathrm{gr} / 100 \mathrm{ml})$ & 1.195 & 0.965 & 1.324 \\
Mineral $(\mathrm{gr} / 100 \mathrm{ml})$ & 0.3 & 0.3 & 0.2 \\
\hline
\end{tabular}




\begin{tabular}{llll}
\hline Imunoglubin: & & - & \\
Ig A (gr/100ml) & 335.9 & - & 119.6 \\
Ig G (gr/100ml) & 5.9 & - & 2.9 \\
Ig M (gr/100ml) & 17.1 & - & 2.9 \\
Lisosin (gr/100ml) & $14.2-16,4$ & - & $24.3-27.5$ \\
Lactoferin & $420-520$ & & $250-270$
\end{tabular}

Source: Maryunani, Anik, 2012.

\subsubsection{Volume of Breastmilk}

In the last week of pregnancy, the milk-producing glands begin to produce milk. From this number will continue to grow until it reaches $400-450 \mathrm{ml}$ by the time the baby is 2 weeks old. Over the next several months a healthy baby will consume about 700-800 ml of breast milk per day. This amount of breast milk will be reached when the baby was breastfed for the first 4-6 months. During this time, breast milk was able to meet the nutritional needs of the baby. In a state of normal milk production, the largest volume of milk that can be obtained is 5 minutes. Suction by infants usually lasts 15-25 minutes (Maryunani \& Anik, 2012). For mothers who are malnourished, the amount of milk in a day is around 500-700 ml for the first 6 months, $400-600 \mathrm{ml}$ in the second 6 months, and 300-500 ml in the second year of the baby's life. However, sometimes an increase in the amount of production of a mother's food consumption does not always increase her milk production (Khasanah \& Nur, 2013). The average amount of milk they give babies during breastfeeding (Kent, 2007):

1). At birth up to $5 \mathrm{ml}$ of first breastfeeding

2). Within 24 hours 7-123 ml/day of breast milk 3-8 feedings

3). Between 2-6 days 395-868 $\mathrm{ml} /$ day of breastfeeding 5-10 feeds

4). One month $395-868 \mathrm{ml} /$ day of 6-18 breastfeeding

5). Six months $710-803 \mathrm{ml} /$ day of breastfeeding 6-18 feedings

Kent also found that babies only emptied their breasts once or twice per day and that an average of 67 percent of the available milk was cweonsumed at an average volume of $76 \mathrm{ml}$ per feed.

\subsubsection{Breastmilk Production Process}

The process of production, secretion and excretion of breast milk was called the lactation process. The process of lactation begins at the beginning of pregnancy due to the influence of hormones during pregnancy (Agnieszka \& Bogusław , 2016). Since the first trimester of pregnancy, the hormone prolactin from the adeno pituitary begins to stimulate the milk glands to produce colostrum until the second trimester of pregnancy. Breast milk was produced in the alveolar corpus then from the alveoli, milk is passed into a duct called the lactiferous duct. After delivery, milk production was affected by the mouth suction of the baby, which stimulates prolactin to come out. The hormone estrogen was a sex hormone produced by the uterus to stimulate the growth of sex organs, such as breasts and public hair, and to regulate the menstrual cycle. In the mother there are 2 kinds of reflexes that determine the success of breastfeeding her baby.

\section{1). Prolactin Reflex (Breast Milk Production)}

The process of milk production begins when stimulated by the baby's mouth suction on the nipple. Suction of the baby will stimulate the nipples because of the sensory nerve endings that function as mechanical receptors. This stimulation is continued to the hypothalamus through the hypothalamic spinal cord and will suppress the secretion of prolactin secretion inhibiting factors and in turn stimulate the secretion of prolactin secretion stimulating factors. The stimulating factor for prolactin secretion will stimulate the anterior pituitary to release prolactin. This hormone functions to make milk.

\section{2). Flow Reflex (Expression of Breast Milk)}

Along with the formation of prolactin by the anterior pituitary, stimulation from the baby's suction was continued to the posterior pituitary (neurohipofise) then released by the hormone oxytocin. Through the bloodstream, this hormone goes to the uterus, causing contractions. The contraction of the cells will squeeze the milk that has been made, out of the alveoli and into the duct system and then flows through the lactiferous ducts into the baby's mouth. Disruption of the let down reflex prevents milk from passing. In this case, the expenditure of breast milk is greatly 
influenced by psychological factors (Maritalia \& Dewi, 2017).

\subsubsection{Factors Affecting Milk Production}

The process of breastfeeding during the first week was a critical period that determines milk production. The success of breastfeeding was influenced by conditions before pregnancy and during breastfeeding, while the conditions before pregnancy also determined by breast development at birth and at puberty. Several factors affect milk production:

\section{1). Mother's food}

The food a breastfeeding mother eats does not directly affect the quality or quantity of milk produced. In the body there are reserves of various nutrients that can be used whenever needed. Mothers need must contain balanced nutrition, namely calories, protein, calcium and vitamin $\mathrm{D}$, magnesium, green vegetables and fruit, complex carbohydrates, fat, salt, DHA, vitamins, zinc and iron.

\section{2). Frequency of breastfeeding}

The frequency of breastfeeding can affect milk production. The frequency of breastfeeding in preterm and term babies is different. Studies say that the production of breast milk for premature babies will be optimal by pumping breast milk more than 5 times per day during the first month after delivery. Whereas for term babies, the frequency of breastfeeding 10 times per day for the first 2 weeks after giving birth is associated with sufficient milk production. So that it is recommended to breastfeed at least 8 times per day in the initial period after giving birth. The frequency of breastfeeding is related to the ability of hormone stimulation in the breast glands.

\section{3). Baby's birth weight}

Low birth weight babies (LBW) have a lower ability to suck breast milk than babies with normal birth weight. Babies born with low birth weight have the ability to suck breast milk, the frequency and duration of breastfeeding are lower than normal birth weight babies, which in turn will affect the stimulation of the hormones prolactin and oxytocin in producing breast milk.

\section{4). Age of gestation at delivery}

Gestational age and birth weight affect milk production. This is due to babies born prematurely (gestational age less than 34 weeks) are very weak and unable to suck effectively, the weak ability to suck in premature babies can be caused by low body and imperfect organ function.

\section{5). Use of contraceptives}

For mothers who are breastfeeding, it is not recommended to use contraceptive pills that contain the hormone estrogen because this can reduce the amount of milk production. Therefore, the most appropriate contraceptive tool to use is the IUD or spiral because the IUD can stimulate the mother's uterus so that it can indirectly increase the level of the hormone oxytocin, a hormone that can stimulate milk production.

\section{6). Psychological factors}

Breast milk production is strongly influenced by psychological factors. When breastfeeding, a mother needs feel comfort. Mothers with restlessness, lack of confidence, and feelings of stress may fail to breastfeed their babies. As a result, it can suppress the reflex so that breast milk does not produce properly. The results showed that when mothers have high motivation to breastfeed their babies and provide breast milk according to the baby's needs without having to schedule it, the milk production will increase. According to Yusari asih research (2020), there was a significant difference in the motivation of breastfeeding before and after hypnobreastfeeding. Midwives always provide hypnobreastfeeding therapy and lactation education to help increase motivation for breastfeeding as part of efforts to increase exclusive breastfeeding and breastfeeding for up to 2 years or more.

\section{7). Breast care}

Beneficial breast care stimulates the breasts influencing the pituitary to release the hormones prolactin and oxytocin. Physical care of the breasts before the lactation period needs to be done, namely by massaging the breasts during the last 6 weeks of pregnancy. The sequencing is expected if there was a blockage in the duct in the breast it can be avoided so that in time the milk will come out smoothly.

\section{8). Consumption of cigarettes and alcohol}

Smoking can reduce the volume of breast milk because it interferes with the hormones prolactin and oxytocin for milk production. Smoking will stimulate the release of adrenaline whereas adrenaline will inhibit the release of oxytocin. 


\section{9). Mother's Weight loss}

Recent research has found that breastfeeding is active can exclusively help new mothers give birth to restore their weight. Exclusive breastfeeding helps mothers lose more weight during pregnancy faster than those who do not apply exclusive breastfeeding. When pregnant because of a fetus, also because accumulation of fat in the body, these fat reserves actually do prepared as a source of energy in the process of breast milk production. With breastfeeding, the body will produce more milk so fat deposits that function as energy reserves will be used. If the fat deposits shrink, the mother's weight will quickly return to conditions like before pregnancy (Anderson, 2010).

In the International Breastfeeding Journal mentioned that during the first 4 weeks after giving birth, the mother who was combining breast milk with formula milk has decreased weight loss than mothers who provide exclusive breastfeeding. However, this condition reverses after a period of 8 to 12 weeks. Comparing weight loss to body weight before pregnancy, mothers who provide exclusive breastfeeding lose weight more body weight in the periods 2, 4, 8, and 12 weeks after giving birth compared to mothers who combine breast milk with milk formula. In this percentage of weight loss is statistical very significant occurred in exclusively breastfed mothers and not in the group another mother. This weight loss is evident, despite intake calories in nursing mothers are higher and their activity is lower compared to those who don't apply exclusive breastfeeding,

\subsubsection{Effect of Stress on Milk Production}

Stress can be experienced by all mothers after giving birth. According to the high incidence of mothers experiencing post partum blues can affect milk production, thereby affecting the subsequent breastfeeding process. Mothers who experience high stress/anxiety, the hormone cortisol in serum levels and maternal glucose in the umbilical cord will also increase. High levels of the hormone cortisol can inhibit the secretion of prolactin (a hormone that affects milk production). It is important to do supportive and stimulating therapy so that hormones that affect the lactation process such as oxytocin and prolactin increase as well as hormones that can inhibit oxytocin and prolactin release like cortisol will drop (Puspita \& Lutfiana, 2017). The combination of oxytocin massage and Hypno breastfeeding is very effective for optimizing breast milk production in postpartum mothers. the combination of oxytocin massage and Hypno breastfeeding has a 7.4 chance to optimize milk production (Ningsih \& Lestari, 2019).

\subsubsection{Hypnobreastfeeding}

\section{Definition of Hypnosis/Hypnotherapy}

Hypnosis was not as same as with sleep. A person in a hypnotic state, even though his body was resting (like a sleeping person) can still hear clearly and respond to the information he receives from outside. Hypnosis was a sleep-like condition that can be deliberately done to someone. A person in hypnotized can answer questions and accept suggestions without resistance. Hypnosis has been studied scientifically for more than 200 years. Many clinical and experimental studies have tried to determine what is most unique about hypnosis compared to other mental phenomena. Hypnosis was first introduced by James Braid, a well-known doctor in England who lived between 1795-1860. Before James Braid's time, hypnosis was known as Mesmerism or Magnetism (Kusmandi \& Lanny, 2014).

Several techniques that can be used to relax the mind and soul including yoga, tai chi, deep breathing, meditation, visualization, relaxation music, massage therapy, biofeedback and hypnosis. In the 1950s, the first patented hypnosis was hypnobirthing by Mogan, a certified hypnotherapist and hypnoanesthesiologist from New Hampshire, USA. The benefits of hypnosis were not only limited to physical or mental illness healing services, but also useful as hypnotherapy for obstetric cases such as hypnopregnancy (how hypnosis helps in pregnancy programs), hypnobirthing (giving birth without fear and minimizing pain), hypnobreastfeeding (how hypnosis can help increase breastfeeding), hypnoanaesthesia (how hypnosis can help in the process of natural anesthesia), hypnoslimming (losing weight by implanting programs into the subconscious so that you can control your appetite (Harianto, 2010).

\subsubsection{Hypnolactation/Hypnobreastfeeding}

Hypnosis in nursing mothers was called hypnobreastfeeding. Hypnobreastfeeding relaxation technique was an excellent new way or method to build positive intention and motivation in breastfeeding and was able to maximize the quantity and quality of breast milk. Hypnobreastfeeding consists of the word hypno (hypnos which means sleep), which is a fragment of the word hypnosis/hypnotism, namely communication of the subconscious mind and breastfeeding so that the breastfeeding process can take place comfortably because the mother records in the subconscious mind that breastfeeding was a natural and comfortable process ( Andriana, 2017). Regular relaxation was able to balance hormone levels after childbirth, and support milk production and form a positive mindset and 
calmness for breastfeeding, so that mothers can enjoy the breastfeeding process properly. Research shown that repeated relaxation routinely for 20 minutes can increase $63 \%$ milk production. A mother's state of mind can affect lactation, especially the let-down reflex. Stress, anxiety and fatigue can hamper milk supply, so relaxation exercises can be very beneficial both physically and psychologically for both mother and baby. The stress experienced by the mother shortly after the baby is born, as well as the lack of support for breastfeeding, increases the secretion of the hormone cortisol (a hormone that affects stress), which causes milk to come out not smoothly. The basic of hypnobreastfeeding was the utilization of the ability to access the subconscious directly. In a state of sleep, the conscious mind will fall asleep, but the subconscious mind will stay awake. Hypnobreastfeeding can neutralize these negative records for reprogramming by including positive intentions or suggestions for their belief and confidence to be able to provide exclusive breastfeeding for their babies and believing that milk production was sufficient to meet the baby's needs. Hypnobreastfeeding can help mothers by deep relaxation and visualization during pregnancy to make breastfeeding process easier, especially for the first month after giving birth. Most of the people who have practiced relaxation techniques feel a refreshed feeling afterward, calmer and more comfortable mind (Puspita \& Lutfiana, 2017).

\subsubsection{Hypnobreastfeeding Steps}

\section{1). Preparation/Pre Induction}

a. Choose the right time to do relaxation.

b. Perform regular and disciplined exercises for maximum results (at least once a day for 30 minutes)

c. Prepare a place for relaxation (a quiet room with not too bright lights)

d. Suggestibility test (test the ability to reach negligence)

e. Learning channels (modalities)

\section{2). Relaxation/Induction}

Relaxation aims to bring the mother into a hypnotic state. In order to achieve a state of relaxation, its need to practice to achieve a focused mind and to be able to concentrate. After that. it will do relaxation which consists of relaxing muscles, breathing and mind.

\section{3). Isolation}

Isolation aims to protect oneself from outside influences that can interfere with the hypnosis process.

4). Test

This step was used when doing relaxation guided by a therapist. This test to determine whether being treated has entered a hypnotic state.

\section{5). Consolidation}

Consolidation was used if doing relaxation under the guidance of a therapist. The purpose of consolidation was to prepare the client to enter the implantation stage to signs of relaxation.

\section{6). Implantation}

After reach a completely relaxed state, it's time to enter suggestions into the subconscious mind in accordance with the purpose of doing self-hypnosis/hypnobreastfeeding.

\section{7). Termination}

After feeling enough to enter positive suggestions/affirmations related to the smooth production of breast milk, it is time to end the relaxation session. Before ending it, it is better to prepare in advance, and the relaxation session has been completed (Puspita \& Lutfiana. 2017)

\section{Research Methodology}

\subsection{Design}

A non-equivalent control group design was employed in the Quasy experimental study (Sugiyono, 2013). This research investigated the experimental group which is a group of mothers who are given hypnobreastfeeding treatment and those who are not given hypnobreastfeeding treatment as a control group.

\subsection{Population/Sample}

All primiparous breastfeeding mothers who live in Perlis Village, Tangkahan Durian District, Langkat Regency in 2018 , based on information obtained from village midwives where the number of primigravida mothers whose 
estimated births in 4-7 months are 28 people. The sampling used purposive sampling technique with inclusion criteria 1) Breastfeeding mothers who have babies aged 10 days-1 month

2) $\mathrm{Hb}$ of normal mothers ( $\geq 12 \mathrm{gr} \%$ )

3) Infants were not given formula milk during the study.

The exclusion criteria:

1) Abnormal nipple and breast shape.

2) Mothers who suffer from psychological disorders (postpartum blues, postpartum depression).

The research sample was divided into 2 groups, consist of 12 samples for the experimental group that was given hypnobreastfeeding treatment and 12 samples that were not given treatment as the control group.

\subsection{Ethical Considerations}

Ethical Considerations received from the Medan Health Polytechnics Of Ministry Of Health Ethics Committee.

\subsection{Instrument}

The instrument consisted of Measuring $\mathrm{Hb}$ levels using the easy touch brand digital $\mathrm{Hb}$ method and The measuring of device for milk production uses a measuring cup in the Piageon brand breastpump. The instrument was pre-tested and adjudged to have the face and content validity.

\subsection{Data Collection}

The data was collated begins with the determination of the respondents as the research sample according to the inclusion criteria that have been determined, namely primiparous breastfeeding mothers with babies aged 10 days to 1 month. Normal maternal $\mathrm{Hb}$ levels $(\geq 12$ gr\%) were known through the $\mathrm{Hb}$ examination using the easy touch brand digital $\mathrm{Hb}$ method, so that of the 28 primiparous mothers only 24 people met to the criteria. Furthermore, the mother was told not to give formula milk to babies but only breast milk as long as the study was conducted with a frequency of breastfeeding at least 6 times per day. Then the respondents measured the respondent's initial breast milk using the Piageon brand breastpump. Data on milk production in the untreated group and the hypnobreastfeeding group were measured using a measuring cup in the breastpump. In the treated group, hypnobreastfeeding was carried out for 30 minutes in 4 consecutive days followed by measurement of milk production. The measurement of breastmilk production in both groups was carried out before the mother breastfed her baby at the same time, where beforehand the mother had been informed that the last time to breastfeed was $06.00 \mathrm{am}$. After that every result obtained from the respondent is recorded in the observation sheet.

\subsection{Data Analysis}

The results of the normality test using the Kolmogorov-Smirnov test showed that all data on breast milk measurements were normally distributed ( $p>0.05$ ). The $p$ value in the treated group was 0.190 and the untreated group was 0.618 .

\section{Results}

3.1 Socio-Demographic Characteristics

Table 2. Sociodemographic data-N=133

\begin{tabular}{|c|c|c|c|c|}
\hline & \multicolumn{2}{|c|}{ Hypnobreastfeeding Group } & \multicolumn{2}{|c|}{ Untreated group } \\
\hline & $\mathrm{f}$ & $\%$ & $\mathrm{f}$ & $\%$ \\
\hline \multicolumn{5}{|c|}{ Demographic variables } \\
\hline \multicolumn{5}{|l|}{ Age } \\
\hline Under 20 & 0 & 0 & 1 & 8.3 \\
\hline $20-35$ & 12 & 100 & 11 & 91.7 \\
\hline 35 an over & 0 & 0 & 0 & 0 \\
\hline \multicolumn{5}{|l|}{ Job status } \\
\hline Employee & 12 & 100 & 12 & 100 \\
\hline Unemployee & 0 & 0 & 0 & 0 \\
\hline
\end{tabular}




$\begin{array}{lllll}\text { Mother education status } & & & & \\ \text { Basic } & 4 & 33.3 & 5 & 58.3 \\ \text { Middle } & 8 & 66.7 & 0 & 41.7 \\ \text { High } & 0 & 0 & 0 & 0\end{array}$

Table 1 illustrates the distribution of the research participants according to their socio-demographic variables. It shows that 12 respondents in the hypnobreastfeeding group were aged 20-35 years (100\%) while in untreated group most of them were 20-35 years old (91.7\%). Based on the employment status of all respondents, both of groups were in the working category $(100 \%)$. Based on the level of education, the majority of primary education in the group that did not do hypnobreastfeeding $(58.3 \%)$ and secondary education in the group that did hypnobreastfeeding $(66.7 \%)$.

Based on the table above, it is known that 12 respondents in the hypnobreastfeeding group were aged 20-35 years $(100 \%)$. But in untreated group, 11 respondents $(91.7 \%)$ were $20-35$ years old. Based on the work status of all respondents, both of the treated and non-treated groups with hypnobreastfeeding treatment were in the working category $(100 \%)$. And based on the level of education, the untreated group majority in primary education status $(58.3 \%)$ while hypnobreastfeeding group majority in middle education $(66.7 \%)$.

Table 3. Breastfeeding production in breastfeeding mothers that is not resulted by hypnobreastfeeding in Perlis Village, Tangkahan Durian District, Langkat Regency in 2018

\begin{tabular}{lllllllll}
\hline $\mathrm{n}$ & \multicolumn{2}{l}{ Mean per day $(\mathrm{ml})$} & \multicolumn{2}{l}{$\begin{array}{l}\text { Mean } \\
\text { combination }(\mathrm{ml})\end{array}$} & $\begin{array}{l}\text { Min } \\
(\mathrm{ml})\end{array}$ & $\operatorname{Max}(\mathrm{ml})$ & $\mathrm{SD}$ \\
\cline { 2 - 6 } & day 1 & day 2 & day 3 & day 4 & 79.69 & 65 & 100 & 5.44 \\
\hline 12 & 80.17 & 81 & 77.08 & 80.05 & 790 & 65 \\
\hline
\end{tabular}

Table 4. Breastfeeding Production in Breastfeeding Mothers resulted by Hypnobreastfeeding in Perlis Village, Tangkahan Durian District, Langkat Regency in 2018

\begin{tabular}{lllllllll}
\hline $\mathrm{n}$ & \multicolumn{2}{l}{ Mean per day $(\mathrm{ml})$} & & $\begin{array}{l}\text { Mean combination } \\
(\mathrm{ml})\end{array}$ & $\begin{array}{l}\text { Min } \\
(\mathrm{ml})\end{array}$ & Max $(\mathrm{ml})$ & $\mathrm{SD}$ \\
\cline { 2 - 9 } & day 1 & day 2 & Day 3 & day 4 & 78 & 120 & 5.23 \\
\hline 12 & 83,33 & 88.83 & 95.08 & 108.50 & 93.94 & 78 & \\
\hline
\end{tabular}

From the Table 3, the mean milk production of 12 mothers in hypnobreastfeeding group were consistently increased from day one to day four. The combined average of milk production for four days was $93.94 \mathrm{ml}$ with a minimum value of $78 \mathrm{ml}$ and a maximum of $120 \mathrm{ml}$ with SD 5.23 .

Table 5. Effects of Hypnobreastfeeding on Increased Production of Breast Milk in Breastfeeding Mothers in Perlis Village, Tangkahan Durian District, Langkat Regency in 2018

\begin{tabular}{|c|c|c|c|c|}
\hline \multirow[t]{2}{*}{ Variable } & \multicolumn{2}{|c|}{ With Hypnobreastfeeding } & \multicolumn{2}{|c|}{ Without Hypnobreastfeeding } \\
\hline & Mean $\pm S D$ & $p$ value & Mean $\pm S D$ & $p$ value \\
\hline Before & $78.92 \pm 2.15$ & & $79.75 \pm 2.80$ & $0.962^{\mathrm{a})}$ \\
\hline After & $93.94 \pm 5.23$ & $0.001^{\text {a) }}$ & $79.69 \pm 5.44$ & \\
\hline Delta & $15.02 \pm 5.12$ & & $-0.06 \pm 4.49$ & $0.001^{\mathrm{b})}$ \\
\hline
\end{tabular}

${ }^{\text {a) }} p$ value within group (Paired t test).

b) $p$ value between (Independent Sample $t$ test).

From Table 4, it can be seen that in the group that was not hypnobreastfeeding, the average value of milk production was $79.69 \mathrm{ml}$ with a standard deviation of 5.44 and in the hypnobreastfeeding group the average value of milk production was $93.94 \mathrm{ml}$ with a standard deviation of 5.23. The average increase in milk production after 
hypnobreastfeeding was $15.02 \mathrm{ml}$, while in the other group there was no increase in milk production. In fact there was a decrease in milk production by $0.06 \mathrm{ml}$. The results of the statistical test $\mathrm{p}(0.001)<\alpha(0.05)$ showed that there was an effect of hypnobreastfeeding on milk production in the hypnobreastfeeding group, whereas untreated group, there was no effect of not giving hypnobreastfeeding on milk production $(\mathrm{p}(0.962)>\alpha(0.05))$.

\section{Discussion}

The production of breast milk is the result of breast stimulation by the hormone prolactin. This hormone is produced by the anterior pituitary gland at the base of the brain. Breast milk production can be influenced by many factors, namely mother's diet, frequency of breastfeeding, baby birth weight, gestational age at delivery, use of contraception, peace of mind and mind, breast care and consumption of cigarettes and alcohol. The results of this study indicate that the indeterminate production of breast milk in the non-hypnobreastfeeding group can be caused by various factors that exist in the mother and baby. There were differences in prolactin levels before and after hypnobreastfeeding. Based on the results of hypnobreastfeeding research can be an intervention for nursing mothers to succeed in breastfeeding exclusively (Ida Sofiyanti et al., 2019)

The results of the study Maternal age has an effect on milk production, because in this study $91.7 \%$ of mothers were in the healthy reproductive age category so they would produce normal breast milk. In line with Lestari's research (2012) which shows that mothers aged 20-35 years have a lot of milk production. Women aged $<20$ years are considered physically, mentally and psychologically immature in facing breastfeeding exclusively for their babies, while women who give birth over 35 years are considered at risk because it is closely related to nutritional anemia which can affect milk production so that more found problems such as less milk production and fatigue. Based on job status, $100 \%$ of respondents in the group who were not given hypnobreastfeeding were working. This will have an impact where the mother didn't have time to breastfeed her baby and pay attention to the needs of breast milk, therefore in this study the work affects milk production.

This results are in accordance with Ekiawati's opinion in Ayu Dewa's research (2017) that working mothers have limited time to breastfeed their babies. Besides that, the energy drained during work usually makes mothers too tired to breastfeed their babies. Occupation sometimes affects the mother's delay in giving exclusive breastfeeding. In addition, it is also different from the research of Rahmawati and Bisepta (2017) which states that the type of work and education of the mother is a factor that is assumed to influence the increase in the volume of breast milk. Education is the main factor in forming knowledge. Education and knowledge determine a person's attitude in thinking for decision making in breastfeeding.

Therefore, the increase and decrease in milk production in breastfeeding mothers who are not given hypnobreastfeeding is not only influenced by age, education and occupation, but there are still many factors that influence it. The stimulation of the baby's suction sends a message to the hypothalamus that stimulates the anterior pituitary to release prolactin, a hormone that increases milk production by the alveolar cells of the breast glands. The amount of prolactin secreted and the amount of milk produced is related to the size of the suction stimulus, namely the frequency, intensity, and length of time the baby sucks. Maternal psychological factors can also affect the lack of milk production, including mothers who are in a state of stress, confusion, anger and sadness, lack of confidence, too tired, mothers do not like breastfeeding, and lack of support and attention from families and partners to the mother. In line with Kamariyah research (2014) that there is a relationship between the psychological condition of the mother and the smooth production of breast milk. A good psychological condition of the mother can have a good impact on the mother to smooth the production of breast milk. A good psychological condition of the mother will motivate her to breastfeed her baby so that the hormone that plays a role in milk production will increase because milk production, starting from the breastfeeding process, will stimulate milk production. This research is also supported by Werdayanti's (2013) theory which states that psychological factors have a big influence on breast milk production because the release of milk from the breasts is smoother when the mother is relaxed and comfortable. Respondents were given hypnobreastfeeding for 4 consecutive days within 30 minutes and then immediately carried out measurements to assess breast milk production. The results showed that there was an increase every day even though the increase was approximately $10 \mathrm{ml}$. This is because the mother wants to express breastmilk first, relax her mind and intend to continue giving breast milk to her baby.

Age is one of the factors that influence breast milk production in mothers. Mothers who are less than 35 years of age produce more milk than mothers whose age is older, but mothers who are very young (less than 20 years old) have less milk production due to the level of regularity. This result is reinforced with Lestari's research (2012) that breastfeeding is influenced by age of mother, with the most age being in the 20-35 year age range. So the increase in milk production is supported by the age of the mother who is still in the productive age.

Sari (2017) reports that most people who have practiced relaxation techniques feel a fresh feeling afterward, have 
a calmer and more comfortable mind, so that the mother's worries and anxiety can decrease and it will disappear over time so that the mother is more excited and has the confidence to breastfeed. This is also supported by research by Endah et al. (2014) which states that hypnobreastfeeding has a significant effect on the success of exclusive breastfeeding with its effects 3.11 times greater than without hypnobreastfeeding.

In table 4 it is known that the group that was given hypnobreastfeeding experienced an increase in milk production by $15.02 \mathrm{ml}$. The mean initial milk production was $78.92 \mathrm{ml}$ with $\mathrm{SD} \pm 2.15$ and after hypnobreastfeeding was given, it was $93.94 \mathrm{ml}$ with $\mathrm{SD} \pm 5.23$. Meanwhile, in the group not given hypnobreastfeeding, there was no increase in milk production, but there was a decrease in milk production by $0.06 \mathrm{ml}$. Based on the results of the Independent Sample test, the results obtained were $\mathrm{p}(0.001)<\alpha(0.05)$, meaning that Hypnobreastfeeding was proven to significantly increase milk production in breastfeeding mothers.

The mean volume of breastmilk per one breastfeed in mothers who received hypnobreastfeeding always increased compared to mothers who did not receive hypnobreastfeeding. This can be due to the fact that when the mother wants to express milk, the mother first relaxes her mind so that the daily milk production increases. Research has shown that repeated relaxation routinely for 30 minutes can increase milk production by $63 \%$.

Breast milk production is influenced by the hormones prolactin and oxytocin. The production of these two hormones is greatly influenced by the psychological condition of the mother. Hypnobreastfeeding relaxation is an excellent new way or method to build positive intention and motivation in breastfeeding and is able to maximize the quantity and quality of breast milk. This is in line with the research of Ayu Dewa (2017) which states that there is an effect of hypnobreastfeeding on the motivation of breastfeeding mothers in exclusive breastfeeding, the more often hypnobreastfeeding is done, the better the motivation to provide exclusive breastfeeding.

Hypnobreastfeeding can provide peace to nursing mothers. The more calm and confident the mother is, the more prolactin and oxytocin hormones are produced. This is in line with the research of Aini et al. (2017) and Lutfiana et al. (2017) that there is a significant increase between the combination of oxytocin massage and hypnobreastfeeding on uterine involution and an increase in the hormone prolactin in postpartum mothers at the Semarang public hospital. The results showed that the increase in prolactin in the experimental group was greater than that in the control group. Research by Anuhgerah et al. (2017) also said that hypnotherapy is more effective than acupressure to stimulate the production of the hormone prolactin and milk production in breastfeeding mothers with C-section. Therefore, hypnotherapy techniques can be used as an alternative to the success of exclusive breastfeeding.

This is also supported by research by Dini et al. (2017) that there is an effect of hypnobreastfeeding and oxytocin massage on breast milk production in postpartum mothers. Hypnobreastfeeding and oxytocin massage both had an effect on increasing breast milk production even though the hypnobreastfeeding group had more milk production increases than the group given oxytocin massage, but if hypnobreastfeeding and combined oxytocin massage would have a very large effect. Sari et al. (2017) also said that a combination of oxytocin massage and hypnobreastfeeding can effectively reduce anxiety and increase milk production in nursing mothers. Based on the results of this study, hypnobreastfeeding can increase milk production in nursing mothers.

Hypno breastfeeding technique is a natural effort to use subconscious energy given to postpartum mothers so that the breastfeeding process runs safely and smoothly. This effort is done by entering positive affirmation or suggestion when the mother is very relaxed or very concentrated on a goal so that mother can produce enough milk for the infants growing needs. But, according to the research by Nur Masruroh, Ratna Ariesta Dwi Andriani (2018) that breastfeeding with hypno reduces the onset of colostrum ejection but is not statistically significant.

\subsection{Recommendations}

We recommend an exploration of this other causal barriers to milk production in breastfeeding mothers include another obstacle in terms of biomolecular is due to genetic factors. In Perlis Village, Tangkahan Durian District, Langkat Regency, we recommend and encouraging working mothers to motivate themselves to keep giving breast milk wholeheartedly even though they are busy working with attention to balanced nutrition and adequate rest.

\section{Conclusion}

Breast milk production in ungiven hypnobreastfeeding group have alteration erratically, whereas in mothers with hypnobreastfeeding treated it increased consistently. Hypnobreastfeeding treatment has been shown to significantly increase milk production in breasfeeding mothers.

\section{Acknowledgmentss}

Acknowledgments this study was supported by the funding from: Primary Research on Higher Education of the Ministry of Research, Technology and Higher Education of the Republic of Indonesia for the 2019 Fiscal Year 
(Competing Interests Statement There is no conflict of interest inflicted in this study

\section{Competing Interests Statement}

The authors declare that there are no competing or potential conflicts of interest inflicted in this study.

\section{References}

Aini, Y. N., Hadi, H., Rahayu, S., Pramono, N., \& Mulyantoro, D. K. (2017). Effect OF Combination of Oxytocin Massage and Hypnobreastfeeding on Uterine Involution and Prolactin Levels in Postpartum Mothers. Belitung Nursing Journal, 3(3), 213-220.

Anuhgera, D., Thahjono, K., Sumarni, S., Mardiyono, M., \& Ari, S. (2017). Hypnoteraphy is more effective than acupressure in the production of prolactin hormone and breast milk among women having given birth with caesarean section. The journal of perinatal education, 12(3), 16-41.

Arikunto \& Suharsimi. (2010). Research procedures: A practical approach Rineka Cipta Jakarta.

Asih, Y., \& Aziza, N. (2020). Hypnobreastfeeding to Increase Motivation and Breast Milk Production: A Study (Doctoral dissertation, Poltekkes Tanjungkarang).

Ayu, D. (2017). The Effect of Hypnobreastfeeding on Motivation of Breastfeeding Mothers in Giving Exclusive Breastfeeding in Ngampin Village, Ambarawa District, Semarang Regency (Faculty of Health Sciences, D4 Midwifery, Ngudi Waluyo University).

Cadwell, K., \& Cindy, T.-M. (2013). Handbook of Lactation Management. Jakarta: EGC

Donna T. G. (2007). The anatomy of the lactating breast Latest research and clinical implications. Infant Journal, $3(2)$.

Eva, P., Hermanu, J., \& Eti, P. (2016). Exclusive Breast Feeding Management: Qualitative Study on Working Mothers in Kalibawang District, Kulon Progo. Yogyakarta Journal of Health Policy and Management, 1(1), 13-19. https://doi.org/10.26911/thejhpm.2016.01.01.03

Ida, S., Fitria, P. A., \& Hapsari, W. (2019). Application of Hypnobreastfeeding in Breastfeeding Mothers. Indonesian Journal of Midwifery (IJM). Retrieved from http://jurnal.unw.ac.id/index.php/ijm

Jama, A., Gebreyesus, H., Wubayehu, T., Gebregyorgis, T., Teweldemedhin, M., Berhe, T., \& Berhe, N. (2020). Exclusive breastfeeding for the first six months of life and its associated factors among children age 6-24 months in Burao district, Somaliland. International breastfeeding journal, 15(1), 5. https://doi.org/10.1186/s13006-020-0252-7

Kamariyah, N. (2014). Psychological Conditions Affecting Breastfeeding Mother's Milk Production at Bps Aski Pakis Sido Kumpul Surabaya. Health Scientific Journal, 7 (12), 29-36.

Kristiyanasari, W. (2011). Breastfeeding, Breastfeeding and BSE. Yogyakarta: Nuha Medika.

Kuswandi, L. (2014). Hypno-birthing A Gentle Way to Give Birth. Jakarta: Pustaka Bunda

Lestari, A. (2012). Motivation of working mothers in giving exclusive breastfeeding at PT. Dewhirts Men's Wear Indonesia. Students journal, 1(1). Bandung: FIK Padjadjaran University.

Maritalia, \& Dewi. (2017). Midwifery Care In postpartum and breastfeeding mothers. Yogyakarta: Learning Library.

Marmi, (2014). Midwifery care during the puerperium "Puerperium Care”. Yogyakarta: Student Library.

Maryunani, A. (2012). Early Initiation of Exclusive Breastfeeding and Lactation Management. Jakarta.

Masruroh, N., \& Andriani, R. A. D. (2018). Effect of Hypno Breastfeeding On Colostrum Ejection Onset In Primiparous Mothers. In Proceeding the 4th International Conference On Public Health. Universitas Sebelas Maret Surakarta.

Ministry of Health. (2018). Indonesian Health Profile 2018. Jakarta. Retrieved 11 November, 2017, from http://www.depkes.go.id/resources/download/pusdatin/profi-kHealth-indonesia/Profil-Kesehatan-Indonesia2016.pdf

Motee, A., \& Jeewon, R. (2014). Importance of exclusive breastfeeding and complementary feeding among infants. Current Research in Nutrition and Food Science Journal, 2(2), 56-72. https://doi.org/10.12944/CRNFSJ.2.2.02

Ningsih, F., \& Lestari, R. M. (2019). Efektifitas Kombinasi Pijat Oksitosin dan Hypno Breastfeeding terhadap 
Optimalisasi Produksi ASI pada Ibu Nifas. Jurnal Surya Medika (JSM), 5(1), $174-187$. https://doi.org/10.33084/jsm.v5i1.958

North Sumatra Health Office. (2013). Health Profile of North Sumatra Province 2012. Retrieved December 20, 2017, from http://www.depkles.go.id/resources/download/profil/province health profile 2012/02 Profile of Kes Prov. North Sumatra 2012.pdf

Notoadmojo, S. (2010). Health Research Methodology. Jakarta: Rineka Cipta.

Pollard, M. (2016). Breastfeeding Evidence-based care. Jakarta: EGC.

Prasetyono, D. S. (2012). Exclusive Breastfeeding Smart Book. Jogjakarta DIVA Press.

Rahmawati, A., \& Bisepta, P. (2017). Hypnobreastfeeding to increase milk production in working nursing mothers. National Seminar and Product Title.

Sari, L. P., Salimo, H., \& Budihastuti, U. R. (2017). Optimizing the combination of oxytocin massage and hypnobreastfeeding for breast milk production among post-partum mothers. Journal of Maternal and Child Health, 2(01), 20-29. https://doi.org/10.26911/thejmch.2017.02.01.03

Yusari, A. (2020). Hypnobreastfeeding and Motivation of Breastfeeding. Journal of Health, Poltekkes Ministry of Health Tanjung Karang.

Żelaźniewicz, A., \& Pawłowski, B. (2019). Maternal breast volume in pregnancy and lactation capacity. American journal of physical anthropology, 168(1), 180-189.

\section{Copyrights}

Copyright for this article is retained by the author(s), with first publication rights granted to the journal.

This is an open-access article distributed under the terms and conditions of the Creative Commons Attribution license (http://creativecommons.org/licenses/by/4.0/). 